\title{
EMPLOYMENT GROWTH AND LABOUR ELASTICITY IN V4 COUNTRIES: STRUCTURAL DECOMPOSITION ANALYSIS
}

\author{
Martin Hudcovský, Martin Lábaj, Karol Morvay*
}

\begin{abstract}
In the present paper, we analyse the determinants of employment growth in V4 countries. While a standard approach relies on the parametric estimation of labour elasticity coefficients, we employ a novel approach based on structural decomposition analysis. This allows us to identify several determinants which mitigate the effects of economic growth on employment. We decompose the overall change in employment into the contribution of six factors: changes in labour productivity, changes in the import of intermediate products, changes in the structure of production, changes in the final demand structure by industries and by sectors, and a change in final demand volume. We show that besides the generally accepted influence of labour productivity growth on employment, other factors such as structural changes and changes in final demand played an important role in employment changes. These results shed some light on low labour elasticity in V4 countries and go beyond the simple labour productivity growth argument.
\end{abstract}

Keywords: structural decomposition analysis, labour elasticity, V4 countries, employment JEL Classification: C67, J21

\section{Introduction}

In recent years, the jobless growth phenomenon received much attention both in the media and the academic literature. Authors using the employment elasticity approach studied a broad cross-section of countries around the world to explain why such a phenomenon occurred in economies during the last decade. Kapsos (2005) estimated that globally world employment elasticity is around 0.3 , with significant differences from region to region. This result implies that the intensity of the response of employment to changes in economic growth is approximately 30\%. Using a sample of 10 largest states in the US, Döpke (2001) estimated the employment intensity of economic growth to be 0.5 . The higher value is attributable to the more flexible labour market and the growth of labour productivity. While jobless growth was present in many developed countries to some extent, it has been even more pronounced in V4 countries over the past decade. High economic growth in these countries led to moderate increases in employment but the employment

* Martin Hudcovský, Department of Economic Policy, Faculty of National Economy, University of Economics in Bratislava, Slovakia; Institute of Economic Research, Slovak Academy of Sciences, Slovakia (martin.hudcovsky@euba.sk);

Martin Lábaj, Department of Economic Policy, Faculty of National Economy, University of Economics in Bratislava, Slovakia; Institute of Economic Research, Slovak Academy of Sciences, Slovakia (martin.labaj@euba.sk);

Karol Morvay, Department of Economic Policy, Faculty of National Economy, University of Economics in Bratislava, Slovakia; Institute of Economic Research, Slovak Academy of Sciences, Slovakia (karol.morvay@euba.sk).

This article is a part of research Project VEGA 1/0313/14 "Relation between Efficiency and Equity Implications for Economic Policy" (50 \%) and Project VEGA 2/0070/15 "The Dynamics and Nature of Changes in the Slovak Economy in the Phase of Expected Stabilisation of Economic Growth" (50\%). 
elasticity remains low relative to other country groups. For the region of the V4 countries, the estimated elasticity was far below the average, approximately 0.1 . It is argued that the main determinant of such unresponsiveness of labour market was caused by the growth of labour productivity. However, this observation leads to contradictory policy conclusions. On the one hand, it is argued that these countries need high labour productivity growth to close the technological gap to the most advanced countries. On the other hand, it is argued that lower labour productivity growth would be more favourable to employment growth. In this paper, we show that it is necessary to take into account a number of factors besides labour productivity growth and labour market mismatch in order to explain the observed labour elasticity. Among these, the changes in the structure of production and changes in final demand structure (both at industry and sector level) are crucial. These results provide more policy options that could go beyond the trade-off between labour productivity growth and employment growth.

Furceri, Crivelli, and Toujas-Bernate (2012) were the first to test the role of economic structure on employment elasticity. While their estimations point to a strong positive effect, they do not provide an in-depth analysis of the relationship. A structural decomposition analysis based on input-output models can provide more concrete evidence regarding the determinants of employment elasticity. Among other advantages, these models capture complex relations among industries and between the intermediate and final use of production and they model the link between the employment, economic structure and final demand explicitly. The impact of structural changes and labour productivity changes on an economy has been widely studied mostly at the national level. Structural decomposition became the main analytical tool for such studies since the first regularly published input-output tables became available. Due the complexity of their construction, most studies utilised just a couple of input-output tables even though in some cases they covered an extended period. Skolka (1989) studied structural changes of Austrian economy during 1964-1976. One of the analysed factors was a change in employment. The analysis came to a conclusion that aggregate change in the structure of domestic and foreign final demand was the main driver of employment development. The changes in industry structure of employment occurred mainly due to different rates of labour productivity growth among individual industries. Also, the change in technologies used in the economy (expressed by changes in Leontief inverse matrix) played a significant role in explaining the development of the whole economy and employment as well. Ciobanu, Mattas, and Psaltopoulos (2004) used a structural decomposition approach to analyse the development of the South-East European region. They conclude that in the case of employment, the contribution of technological change had a great impact on labour requirements reduction in the period 1980-1997. Huachu (2008) focussed on the development of China between 1997 and 2002. Based on the decomposition analysis, he created individual scenarios for the development of employment according to the performance of selected variables. The highest contribution to employment growth was recorded in export; on the other hand, the major adverse effect was attributed to the technological progress of the economy. Yang and Lahr (2010) use a wider time span (1985-2007) to study the effects of structural change on labour productivity in the same country. Gunluk-Senesen and Senesen (2011) utilised structural decomposition of labour demand for the identification of the industries capable of generating the highest amount of job positions in Turkey for the year 2002 . The motivation for this analysis was a situation in the labour market which was similar to the one which occurred in V4 countries - strong economic growth with almost no effect on total 
employment in the country. The authors identify the trade industry as the highest potential job creation industry for males and the textile industry as the largest potential driver of employment for women. The paper by Vries and Erumban (2012) is the first one analysing the employment development in the BRIC countries. They identify a positive contribution of labour force reallocation to employment growth in Russia, India and China. Moreover, the latest paper in the field of structural decomposition focussed on employment changes is by Tin (2014) where he pays attention to the development of the Malaysian economy. There are three input-output tables used for decomposition (1970, 1991 and 2000). The main contributor to employment growth in the first period was the change in the structure of domestic final demand. In the second term, the change in export contributed the most. So far, there has been no research which analyses the development of employment in the area of Central Europe with the use of a structural decomposition approach. However, the phenomenon of jobless growth creates ideal conditions to perform such an analysis. Also, an explicit focus on the link between labour elasticity, labour productivity and changes in economic structure is missing in previous analyses. Besides an empirical analysis of the employment growth development in V4 countries, our approach contributes to a better understanding of the links between these determinants and allows us to analyse them explicitly in a much wider context.

\section{Data and Methodology}

The data used in the analysis are from the World Input-Output Database ${ }^{1}$ (WIOD). The database covers 27 European Union countries and other 13 major countries in the world for the period from 1995 to 2011. We use the data for V4 countries (the Czech Republic, Hungary, Poland and Slovakia). Two types of sources are used from this database. First, World Input-Output Tables in current and previous years' prices, denoted in millions of dollars. Second, Socio-Economic Accounts in which employment data by industries are available. World Input-Output Tables are constructed for 35 industries. World InputOutput Tables in previous years' prices are only available for the period from 1995 to 2009. The analysis of the last period (2009-2011) is based on World Input-Output Tables in current prices and so it is not directly comparable to previous periods. We discuss the implications of using current prices in Section 3 in which we present the main results. More information on the construction of the World Input-Output Tables can be found in Dietzenbacher, Los et al. (2013).

\subsection{Input-output model with employment effects}

The Open Static Leontief model is a widely used empirical method that allows us to analyse the complex linkages among industries. When assuming a fixed industrial input structure, it is able to compute the total production that is necessary to satisfy an exogenously given final demand. The basic equation of the model looks as follows

$$
\mathbf{x}=\left(\mathbf{I}-\mathbf{A}^{D}\right)^{-1} \mathbf{f}
$$

Where $\mathbf{x}$ stands for a total production vector, $\mathbf{f}$ for a final demand vector and $\mathbf{A}^{D}$ for a matrix of input coefficients. The upper index $D$ indicates the use of domestic intermediate

1 World Input-Output Database - available at: http://www.wiod.org/new_site/home.htm. 
products. Matrix $\left(\mathbf{I}-\mathbf{A}^{D}\right)^{-1}$ is called a Leontief inverse and its elements represent the amount of production from industry $i$ that is necessary to satisfy one unit of final demand for commodities from industry $j$. A detailed description of the properties and assumptions behind the input-output model can be found in Miller and Blair (2009).

If we assume fixed proportions between labour requirements and total production by industries, that can be expressed in following way

$$
l_{j}=\frac{e_{j}}{x_{j}}, j=1, \ldots, n
$$

Then the model can be augmented by the effects of final demand on total employment in the economy. The elements of the vector $\mathbf{I}=\left\{l_{j}\right\}$ are direct labour coefficients computed as a ratio between employment in industry $j$ and total production of industry $j$. The inverse value of direct labour coefficients is labour productivity. The augmented input-output model then takes this form

$$
E=\mathbf{l}^{\prime}\left(\mathbf{I}-\mathbf{A}^{D}\right)^{-1} \mathbf{f}
$$

Where $E$ is the total employment in the economy. There are three determinants of the employment given by Equation 3: the labour requirements per one unit of production (inverse of labour productivity), the structure of the production represented by the Leontief inverse matrix and the final demand vector $\mathbf{f}$. Further, we can decompose the input coefficient matrix $\mathbf{A}^{D}$ into two components and the final demand vector $\mathbf{f}$ into three components. The use of intermediate domestic products per unit of production is given by the total use of intermediate goods and the equal share of domestic intermediates in total inputs. Thus, matrix $\mathbf{A}^{D}=\mathbf{D} \circ \mathbf{A}^{T}$, where $\mathbf{D}$ is a matrix of import shares of domestic products, $\mathbf{A}^{T}$ is a matrix of total input coefficients based on domestic and imported commodities and the symbol $\circ$ represents the element-wise multiplication of the matrices (Hadamard product). Input-output tables provide the information about the final demand by industries as well as by final demand categories (final consumption expenditures of households, final consumption of government, gross capital formation and export). From this, we can calculate the share of each final demand category in the final demand $\mathbf{s}$ and the share of each industry in the total final demand of a particular final demand category $\mathbf{B}$. The final demand vector is then given by this expression: $\mathbf{f}=\mathbf{B s} F$, where $F$ is the total volume of final demand. Taking these factors into account explicitly, the Equation 3 takes the following form

$$
E=\mathbf{l}^{\prime}\left(\mathbf{I}-\mathbf{D} \circ \mathbf{A}^{T}\right)^{-1} \mathbf{B s} F
$$

From Equation 4 we can conclude that the total employment in the economy depends explicitly on six factors. Labour productivity and volume of final demand, usually analysed in previous studies, are just two of them. We will elaborate more on this in the following sections.

\subsection{Multiplicative structural decomposition analysis}

Structural decomposition analysis aims at disentangling an aggregate change in a variable into its $n$ factors. It can be done in additive form where the aggregate change in each variable is the difference between its value in a comparison period 1 and its value in a base period 0 $\left(\Delta V=V_{1}-V_{0}\right)$, or in a multiplicative form $\left(D V=\frac{V_{1}}{V_{0}}\right)$. We will focus on the multiplicative 
decomposition since our goal is to decompose the index of employment growth into the contribution of particular determinants. We can illustrate the decomposition into two factors on prices and quantities. Let's assume that a price vector $\mathbf{p}_{1}$ and a vector of quantities $\mathbf{q}_{1}$ are available in the comparison period and that corresponding vectors of prices $\mathbf{p}_{0}$ and quantities $\mathbf{q}_{0}$ in the base period have also been sampled. Then, the aggregate value $V$ in both periods equals to

$$
\begin{aligned}
& V_{1}=\mathbf{p}_{1}^{\prime} \mathbf{q}_{1} \\
& V_{0}=\mathbf{p}_{0}^{\prime} \mathbf{q}_{0}
\end{aligned}
$$

The aggregate change in a multiplicative form is thus given by

$$
D V=\frac{V_{1}}{V_{2}}=\frac{\mathbf{p}_{1}^{\prime} \mathbf{q}_{1}}{\mathbf{p}_{0}^{\prime} \mathbf{q}_{0}}
$$

Structural decomposition analysis aims at the decomposition of Equation 6 into the contribution of the change in prices and quantities. The first elementary decomposition equals to

$$
D V=\frac{\mathbf{p}_{1}^{\prime} \mathbf{q}_{0}}{\mathbf{p}_{0}^{\prime} \mathbf{q}_{0}} \times \frac{\mathbf{p}_{1}^{\prime} \mathbf{q}_{1}}{\mathbf{p}_{1}^{\prime} \mathbf{q}_{0}}=P^{L} \times Q^{P}
$$

The change in prices is weighted by quantities from the base period while the change in quantity is weighted by prices in the comparison period. This decomposition is exact because the multiplication of both factors leads to the aggregate change. In index number theory, the first term is the Laspeyres price index and the second one the Paasche quantity index. The second elementary decomposition is obtained by reversing the time periods in the weights.

$$
D V=\frac{\mathbf{p}_{1}^{\prime} \mathbf{q}_{1}}{\mathbf{p}_{0}^{\prime} \mathbf{q}_{1}} \times \frac{\mathbf{p}_{0}^{\prime} \mathbf{q}_{1}}{\mathbf{p}_{0}^{\prime} \mathbf{q}_{0}}=P^{P} \times Q^{L}
$$

Now, the change in prices is weighted by quantities in comparison period, the Paasche price index, and the change in quantities is weighted by prices in the base period, the Laspeyres quantity index. Neither the first nor the second decomposition can be preferred to the other one from a theoretical point of view. On the other hand, it is evident that the contribution of the factors differs. The typical solution adopted in structural decomposition analysis is to take the geometric mean of the two elementary decompositions.

$$
D V=\left(P^{L} \times P^{P}\right)^{1 / 2}\left(Q^{P} \times Q^{L}\right)^{1 / 2}=P^{F} \times Q^{F}
$$

The first term is the Fisher price index and the second one is the Fisher quantity index. This decomposition meets the requirement of time reversal as well as of factor reversal (De Boer, 2009).

\subsection{Multiplicative structural decomposition analysis of employment changes}

If we use an index 1 for a comparison period and index 0 for a base period, then the index of employment change between two periods is given by 


$$
\frac{E_{1}}{E_{0}}=\frac{\mathbf{l}_{1}^{\prime}\left(\mathbf{I}-\mathbf{D}_{1} \circ \mathbf{A}_{1}^{T}\right)^{-1} \mathbf{B}_{1} \mathbf{s}_{1} F_{1}}{\mathbf{l}_{0}^{\prime}\left(\mathbf{I}-\mathbf{D}_{0} \circ \mathbf{A}_{0}^{T}\right)^{-1} \mathbf{B}_{0} \mathbf{s}_{0} F_{0}}
$$

The overall change in employment, measured as an employment index, is given by the change in the six factors described above, such that

$$
D_{E}=\frac{E_{1}}{E_{0}}=D_{l} \times D_{D} \times D_{A} \times D_{B} \times D_{s} \times D_{F}
$$

where $D_{E}$ the index of employment

$D_{l}$ weighted change in labour productivity (or direct labour intensity)

$D_{D}$ weighted change in import shares

$D_{A}$ weighted change in total input coefficient matrix

$D_{B}$ weighted change in final demand structure by industries

$D_{s}$ weighted change in final demand structure by sectors (by final demand categories)

$D_{F}$ weighted change in final demand volume.

The first polar decomposition starts with the weights in the base period for the first factor and ends with the weights in the comparison period for the last factor. In this way, the first polar decomposition takes the following form

$$
\begin{aligned}
& D_{l}^{1}=\frac{\mathbf{l}_{1}^{1}\left(\mathbf{I}-\mathbf{D}_{0} \circ \mathbf{A}_{0}^{T}\right)^{-1} \mathbf{B}_{0} \mathbf{s}_{0} F_{0}}{\mathbf{l}_{0}^{\prime}\left(\mathbf{I}-\mathbf{D}_{0} \circ \mathbf{A}_{0}^{T}\right)^{-1} \mathbf{B}_{0} \mathbf{s}_{0} F_{0}} \\
& D_{D}^{1}=\frac{\mathbf{l}_{1}^{\prime}\left(\mathbf{I}-\mathbf{D}_{1} \circ \mathbf{A}_{0}^{T}\right)^{-1} \mathbf{B}_{0} \mathbf{s}_{0} F_{0}}{\mathbf{l}_{1}^{\prime}\left(\mathbf{I}-\mathbf{D}_{0} \circ \mathbf{A}_{0}^{T}\right)^{-1} \mathbf{B}_{0} \mathbf{s}_{0} F_{0}} \\
& D_{A}^{1}=\frac{\mathbf{l}_{1}^{\prime}\left(\mathbf{I}-\mathbf{D}_{1} \circ \mathbf{A}_{1}^{T}\right)^{-1} \mathbf{B}_{0} \mathbf{s}_{0} F_{0}}{\mathbf{l}_{1}^{\prime}\left(\mathbf{I}-\mathbf{D}_{1} \circ \mathbf{A}_{0}^{T}\right)^{-1} \mathbf{B}_{0} \mathbf{s}_{0} F_{0}} \\
& D_{B}^{1}=\frac{\mathbf{l}_{1}^{\prime}\left(\mathbf{I}-\mathbf{D}_{1} \circ \mathbf{A}_{1}^{T}\right)^{-1} \mathbf{B}_{1} \mathbf{s}_{0} F_{0}}{\mathbf{l}_{1}^{\prime}\left(\mathbf{I}-\mathbf{D}_{1} \circ \mathbf{A}_{1}^{T}\right)^{-1} \mathbf{B}_{0} \mathbf{s}_{0} F_{0}} \\
& D_{s}^{1}=\frac{\mathbf{l}_{1}^{\prime}\left(\mathbf{I}-\mathbf{D}_{1} \circ \mathbf{A}_{1}^{T}\right)^{-1} \mathbf{B}_{1} \mathbf{s}_{1} F_{0}}{\mathbf{l}_{1}^{\prime}\left(\mathbf{I}-\mathbf{D}_{1} \circ \mathbf{A}_{1}^{T}\right)^{-1} \mathbf{B}_{1} \mathbf{s}_{0} F_{0}} \\
& D_{F}^{1}=\frac{\mathbf{l}_{1}^{\prime}\left(\mathbf{I}-\mathbf{D}_{1} \circ \mathbf{A}_{1}^{T}\right)^{-1} \mathbf{B}_{1} \mathbf{s}_{1} F_{1}}{\mathbf{l}_{1}^{\prime}\left(\mathbf{I}-\mathbf{D}_{1} \circ \mathbf{A}_{1}^{T}\right)^{-1} \mathbf{B}_{1} \mathbf{s}_{1} F_{0}}
\end{aligned}
$$

The second polar decomposition is obtained by reversing the index for weights. So factors weighted by the base period become weighted by the comparison period and 
the other way round. In this way, we decompose the overall change in employment $D_{E}$ into the contribution of $D_{l}^{2}, D_{D}^{2}, D_{A}^{2}, D_{B}^{2}, D_{s}^{2}$ and $D_{F}^{2}$ (where upper index indicates the second polar decomposition).

From these two polar decompositions, we obtain the final decomposition by calculating the geometric mean for the contribution of each factor. This leads to a decomposition based on the Fischer index. The contribution of the change in labour productivity is for example given by $D_{l}^{F}=\left(D_{l}^{1} \times D_{l}^{2}\right)^{1 / 2}$. The final decomposition presented in the paper is thus expressed by the following formula

$$
D_{E}=\frac{E_{1}}{E_{0}}=D_{l}^{F} \times D_{D}^{F} \times D_{A}^{F} \times D_{B}^{F} \times D_{s}^{F} \times D_{F}^{F}
$$

Where the upper index indicates the Fisher index decomposition.

\section{Empirical Analysis}

The use of the structural decomposition approach allows us to capture the influence of particular determinants on employment development. Among the most interesting determinants there are the contribution of labour intensity (inverse relationship to labour productivity), the contribution of changes in economic structure and the contribution of changes in final demand. To get deeper insights into the determinants of these particular factors, we have decomposed the change in the economic structure into the change in import shares of intermediate consumption and the change in overall economic structure (given by Leontief inverse), as indicated in Equation 13. Further, the factor of final demand change was divided into three components: the change in the structure of final demand by industries, the change in the final demand by sectors and the change in final demand volume.

The whole period (1995-2011) has been split into three qualitatively different periods. The first one, covering the years between 1995 and 2002, is characterised by the decay of the transformation process from a centrally planned to a market-oriented economic system. The second period, 2003-2008, is characterised by the favourable development of economic growth across the whole V4 group of countries. The last period, 2009-2011, is influenced by the Great Recession and subsequent recovery. For this period, data are available in current prices only. Therefore, the comparison with the previous periods is not possible. Even though we can reveal some structural changes in this last period, the results are blurred by several drawbacks of the data in current prices. First, the effect of change in the final demand volume is overestimated because it is not deflated. Second, the changes in relative prices are not taken into account and therefore the structural changes do not reflect the real changes in the linkages between industries. The period 2009-2011 differs to other periods in one another dimension. It is the period of declining employment and labour productivity as well as decreasing final demand volume. But the analysis suggests that the structural changes contributed negatively to employment growth in this period as well with an exception of Slovakia. This phenomenon would require more inspection in the future research.

The main results are summarised in Table 1. They are expressed as average annual indices due to the use of a multiplicative form of decomposition. A multiplication of all six determinants of employment change, (1) to (6), is equal to employment growth index in the particular period. In this way, the overall employment growth is decomposed into these determinants explicitly for each country and each period. Because of reasons listed above we do not compare the results for the years 2009 to 2011 with previous periods. 
Table 1 | Structural Decomposition Analysis of Employment Growth in V4 Countries, 1995-2011 (average annual indices in \%)

\begin{tabular}{|c|c|c|c|c|c|c|c|}
\hline & $\begin{array}{l}\text { Employ- } \\
\text { ment } \\
\text { growth } \\
\text { index }\end{array}$ & $\begin{array}{c}\text { Changes } \\
\text { in labour } \\
\text { produc- } \\
\text { tivity }\end{array}$ & $\begin{array}{c}\text { Changes } \\
\text { in import } \\
\text { of inter- } \\
\text { mediates }\end{array}$ & $\begin{array}{l}\text { Changes } \\
\text { in the } \\
\text { structure of } \\
\text { production }\end{array}$ & $\begin{array}{l}\text { Changes } \\
\text { in the in- } \\
\text { dustrial fi- } \\
\text { nal demand } \\
\text { structure }\end{array}$ & $\begin{array}{l}\text { Changes } \\
\text { in the final } \\
\text { demand } \\
\text { structure } \\
\text { by sectors }\end{array}$ & $\begin{array}{l}\text { Change } \\
\text { in the final } \\
\text { demand } \\
\text { volume }\end{array}$ \\
\hline & & (1) & (2) & (3) & (4) & (5) & (6) \\
\hline \multicolumn{8}{|c|}{ Czech Republic } \\
\hline 1995-2002 & 99.56 & 96.24 & 99.19 & 100.87 & 99.42 & 99.73 & 104.28 \\
\hline 2003-2008 & 100.97 & 95.94 & 99.47 & 100.23 & 99.37 & 99.14 & 107.15 \\
\hline 1995-2008 & 100.02 & 96.1 & 99.32 & 100.57 & 99.4 & 99.46 & 105.59 \\
\hline 2009-2011* & 98.73 & 101.10 & 99.20 & 99.54 & 99.78 & 99.82 & 99.30 \\
\hline \multicolumn{8}{|c|}{ Hungary } \\
\hline 1995-2002 & 100.69 & 97.32 & 98.65 & 99.78 & 98.65 & 98.97 & 107.67 \\
\hline 2003-2008 & 99.57 & 96.92 & 99.36 & 100.16 & 99.44 & 98.79 & 105.07 \\
\hline 1995-2008 & 99.79 & 97.15 & 98.95 & 99.94 & 98.99 & 98.89 & 106.54 \\
\hline 2009-2011* & 99.62 & 103.18 & 99.92 & 100.07 & 100.19 & 99.37 & 96.98 \\
\hline \multicolumn{8}{|c|}{ Poland } \\
\hline 1995-2002 & 99.03 & 95.5 & 99.21 & 99.69 & 99.41 & 99.74 & 105.66 \\
\hline 2003-2008 & 102.27 & 97.37 & 99.67 & 99.64 & 99.28 & 99.52 & 107.05 \\
\hline 1995-2008 & 100.41 & 96.3 & 99.4 & 99.67 & 99.35 & 99.64 & 106.25 \\
\hline 2009-2011* & 99.92 & 102.45 & 99.40 & 99.35 & 99.83 & 99.73 & 99.21 \\
\hline \multicolumn{8}{|c|}{ Slovakia } \\
\hline 1995-2002 & 99.53 & 95.83 & 99.1 & 99.85 & 98.91 & 100.08 & 106.03 \\
\hline 2003-2008 & 101.59 & 95.91 & 99.48 & 98.85 & 98.69 & 98.48 & 110.84 \\
\hline 1995-2008 & 100.41 & 95.87 & 99.26 & 99.42 & 98.82 & 99.39 & 108.06 \\
\hline 2009-2011* & 99.83 & 99.86 & 100.56 & 100.56 & 100.31 & 100.84 & 97.82 \\
\hline
\end{tabular}

Note: For the years 2009-2011, the decomposition is based on data in current prices so the results are not comparable with previous periods.

Source: World Input-Output Database, 2013 Release, authors' calculations.

In a standard approach, the employment elasticity is measured by an elasticity parameter (e.g. employment intensity) obtained from regressing employment growth on final demand growth and a set of other determinants, labour productivity growth in the first place. All the other factors, (2) to (5) are not measured explicitly and therefore the parameters obtained from this approach can be biased. Using the structural decomposition technique, we measure 
their contribution to overall employment growth explicitly. We can see the misleading results from a focus on labour productivity and final demand growth by a simple computational exercise. When we multiply the change in labour productivity and the change in the volume of final demand, we get an estimate of the potential employment growth holding the other factors fixed (indices for (2) and (4) equal 1). We can then compare the potential employment growth with the real employment growth. The difference expressed in percentage points is shown in Table 2.

Table 2 | Difference between Real and Potential Employment Growth in p.p.

\begin{tabular}{|l|c|c|c|c|}
\hline & Czech Republic & Hungary & Poland & Slovakia \\
\hline $\mathbf{1 9 9 5 - 2 0 0 2}$ & 0.80 & 4.09 & 1.88 & 2.08 \\
\hline $\mathbf{2 0 0 3 - 2 0 0 8}$ & 1.83 & 2.26 & 1.96 & 4.72 \\
\hline $\mathbf{1 9 9 5 - 2 0 0 8}$ & 1.45 & 3.71 & 1.91 & 3.19 \\
\hline $\mathbf{2 0 0 9 - 2 0 1 1}$ & 1.67 & 0.45 & 1.71 & -2.14 \\
\hline
\end{tabular}

Source: Authors' calculations

In all V4 countries, the employment growth would have been higher if there was no negative impact of changes in the structure of production and the structure of final demand. The only exception is the last period in Slovakia with stabilizing effect of the structural changes. But the size of the difference is comparably high. Even though we have to take the results in Table 2 as an exercise only, because the real economic changes are interlinked with each other, they highlight the potential bias in the regression-based approach which focuses on overall changes and does not model structural changes explicitly.

In the following subsections, we first analyse the overall employment growth and labour productivity changes across the countries and in different time periods. Then, we focus on the contribution of structural changes to employment growth. In the last subsection, we analyse the contribution of final demand changes and decompose the final demand changes into three components.

\subsection{Employment growth and labour productivity changes}

The catching up process aimed at reducing the technological gap to developed Western countries has played a significant role in the employment development during the early stages of transformation. The technological gap and its continuous diminishing were reflected in the strong increase in labour productivity. From an overall point of view, the increase in labour productivity has a positive influence on value added growth, but from an employment point of view, such strong growth of labour productivity can hamper the adequate growth of employment.

Table 1 shows that during the first period, the average annual employment growth was negative in 3 out of 4 V4 countries. Only Hungary experienced positive average annual growth of employment in that period, mainly due to the large increase in employment growth between 1998 and 2000. This increase was mainly caused by stability measures adopted in previous years when the economy was experiencing strong internal and external imbalances. The quick recovery of the Hungarian economy after the the slowdown 
encouraged employment growth in the following years (from 1998 to 2000) (Greskovits and Bohle, 2001). The second period can be characterized mainly by very positive trends in economic and employment growth. Employment was developing at substantially higher rates. Average annual growth of employment reached more than $2 \%$ in Poland, $1.6 \%$ in Slovakia and around $1 \%$ in the Czech Republic. Only Hungary had an average annual decline of total employment by $0.4 \%$. Overall employment growth over the whole period was very close to zero \% a year in all four Visegrad countries. Average annual employment growth was between $0.2-0.4 \%$. Employment slightly decreased in Hungary and increased by less than $0.5 \%$ per year in Poland and Slovakia. The main reason behind the moderate effect of economic growth on employment over the analysed period is given by labour productivity growth. Changes in labour productivity contributed by 3 to 4 percentage points annually to lower employment growth. In the case of Slovakia, the productivity growth crippled employment growth by 4 p.p. per year. Similar results can be observed for development in the Czech Republic and Poland. This conclusion is in line with long-term trends in employment, labour productivity and structural changes described by Vltavská and Sixta (2015) for the Czech Republic. In Hungary, the analysed effect was equally negative, but in comparison to other countries of V4 significantly lower.

Our results show that labour productivity development is one of the crucial determinants of employment changes in V4. However, labour productivity alone is not able to explain employment behaviour and further determinants need to be included in the analysis.

\subsection{Contribution of structural changes}

As mentioned above, labour productivity was just one determinant that influenced the employment. The changing economic structure has also played a significant role in the process among other variables. This influence of economic change can further be divided into two specific factors. The first one is the share of intermediate consumption of imported products in the total intermediate consumption. The second one is the overall change of economic structure which can be expressed using input-output analysis in the changes of the Leontief inverse matrix.

The first factor has an intuitive economic interpretation. The larger share of imported intermediate products from abroad in total production leads to lower employment because domestic demand for intermediate products generates employment abroad. There are a large number of reasons for this development. One possible explanation lies in the cheaper labour costs or overall price competitiveness of intermediate consumption products abroad when there are more benefits for manufacturers to import such products than to produce them domestically. Another possible reason is that when the manufacturers have no cost advantage in the production of all subcomponents in the domestic country due the capacity reasons they may decide to focus their production only on more sophisticated goods. This results in less sophisticated products being produced by subcontractors abroad. Regardless of whether the first or the second motive prevails, the final effect for employment development is the same: a larger share of imported intermediate products reduces employment growth in the domestic country.

The development of the domestic intermediate consumption share in total intermediate consumption in Figure 1 illustrates the negative trend across all V4 countries. In each country, the share of imported intermediate consumption products was gradually increasing. From the overall economy point of view, this development represents the positive effect 
of increasing international trade, but from the employment point of view, this development was deteriorating the possible employment growth. In the first period, from 1995 to 2002 , the contribution of import changes had the largest negative effect in Hungary. Other V4 countries showed a negative contribution of this development as well with an average size of the effect of around $0.8 \%$. This means that the growth of imports in intermediate products was lowering the employment growth on average by 0.8 percentage points per year. In the second period, from 2003 to 2008, however, the size of the contribution of this determinant decreased and lowered employment growth approximately by 0.5 percentage points per year. This development is in line with what we observed in Figure 1, where the domestic intermediate consumption share decreased rapidly between the years 1995 and 2002 but at much lower speed from 2002 on.

\section{Figure 1 | Development of Percentage Share of Domestic Intermediate Consumption in Total Intermediate Consumption in V4 countries $(\%, 1995-2011)$}

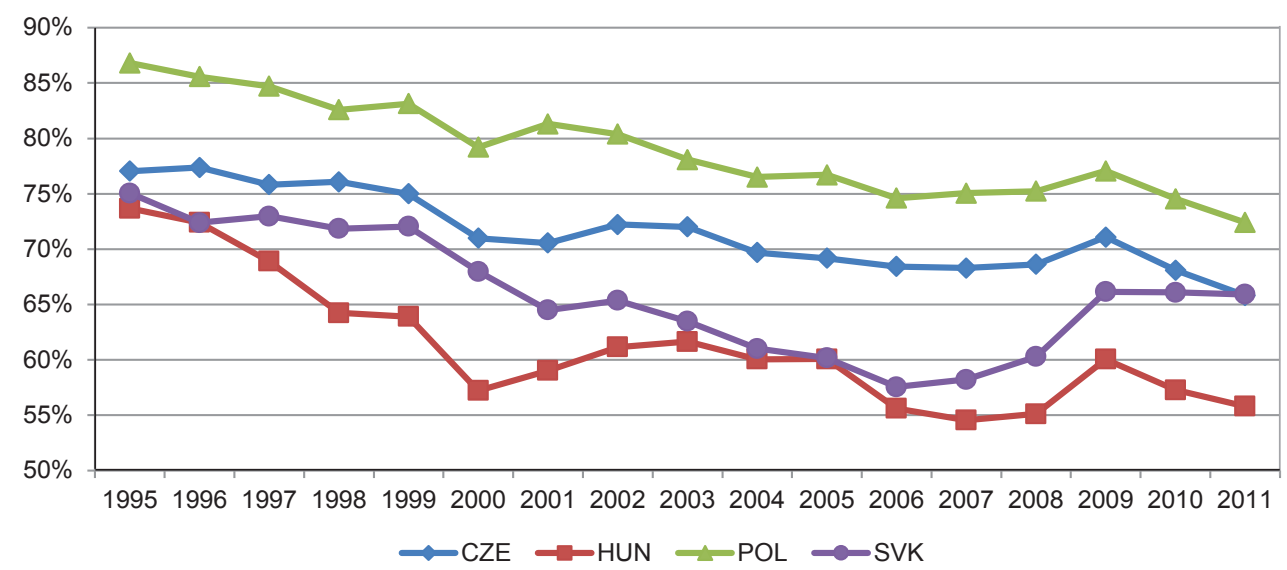

Source: WIOD, authors' calculations

Over the entire period (1995-2008) this factor had a negative impact on employment growth with the largest effect in Hungary, where the average contribution to employment changes was around one percentage point. Slightly lower values, even though still negative, were also reported in other countries of the V4 group. Regarding magnitude, the development of intermediate product imports was a less important determinant of employment growth than changes in labour productivity. However, the employment was still negatively affected by its development.

The second factor, when considering changes in the economic structure, is the change of links within the economy among all sectors. The structure of links among the sectors is expressed by the Leontief inverse matrix, which indicates how much of product in the $i$-th sector must be produced to supply one unit of the $j$-th sector to final demand (Miller and Blair, 2009). The change in the Leontief inverse matrix represents the change of technology used by various sectors and how they evolve over time. The overall contribution of the changes in the Leontief inverse matrix incorporates both positive and negative effects on employment. If for example firms in one sector change their production technology in such a way 
that they increase the use of intermediate products that were produced by lower labour requirements, then the overall change in the Leontief matrix would have a negative impact on overall employment. When observing the impact of changes in technology that have been used in an economy, the only country where the changes have had a positive impact on employment development is the Czech Republic. Especially in the first period, changes in technology affected employment growth positively with a magnitude of about one percentage point per year. In the second period, this positive effect almost disappeared and came close to insignificant values. On the contrary, the contribution of changes in technology was negative in the remaining V4 countries although its size was only marginal. The only exception was the contribution of this variable in the second period in Hungary. Overall, we can conclude that the contribution of changes in the structure of production is almost insignificant regarding employment effects, especially in Hungary and Poland. However, in the Czech Republic, the average contribution of changes in the structure of production to employment was approximately 0.5 percentage points. Slovakia reached similar values to the Czech Republic in magnitude, but in the opposite direction.

\subsection{Contribution of final demand changes}

The last determinant of employment growth included in our analysis is the contribution of final demand changes. Changes in final demand are analysed in three dimensions. First, we analyse the industrial structure of final demand; then we analyse the changes in final demand by sectors (final demand categories) and finally we analyse the contribution of the changes in final demand volume.

The transformation process which took place in all V4 countries did not contribute to employment growth positively. This was partly due to the fact that when transformed companies were exposed to global competition many of them went bankrupt. Furthermore, the transformation process led indirectly to structural changes in final demand which had negative effects on employment. Labour intensive branches in manufacturing, such as the textile industry gradually disappeared and were replaced by new branches, which are characterized by their lower labour intensity of production. Manufacturing of vehicles or electronic and optic equipment can be included into these "new" industries.

This change has negatively affected employment development in all V4 countries during the first period. Mostly in Hungary and Slovakia, where the average annual contribution of this determinant decreased employment growth by more than one percentage point per year. In the second period, from 2003 to 2008, the negative contribution to employment growth slowed down to a level of around 0.6 percentage points per year in all countries, expect Slovakia, where industrial structural change weakened employment growth by approximately 1.3 percentage points per year. By extending the decomposition to the whole period, we can conclude that the negative tendency which occurred had the largest negative impact on employment development in Slovakia and in the first period in Hungary. In the Czech Republic and Poland, such industrial structural change did not have a substantial impact on employment development.

Three out of four V4 countries gradually became small open economies with a significant part of their production delivered to export. Only Poland represents a country with a relatively high domestic market. Therefore, its development depends on export to a lesser extent than than in other V4 countries. This is confirmed in Figure 3 where the significant 
and rapid growth of export share in total production can be identified in the case of Slovakia, the Czech Republic and Hungary. Poland shares with them the same growth of export, but at a substantially lower level.

Figure 2 | Development of "New" Manufacturing Industries Value Added Share in Total Value Added in Manufacturing in V4 (\%, 1995-2011)

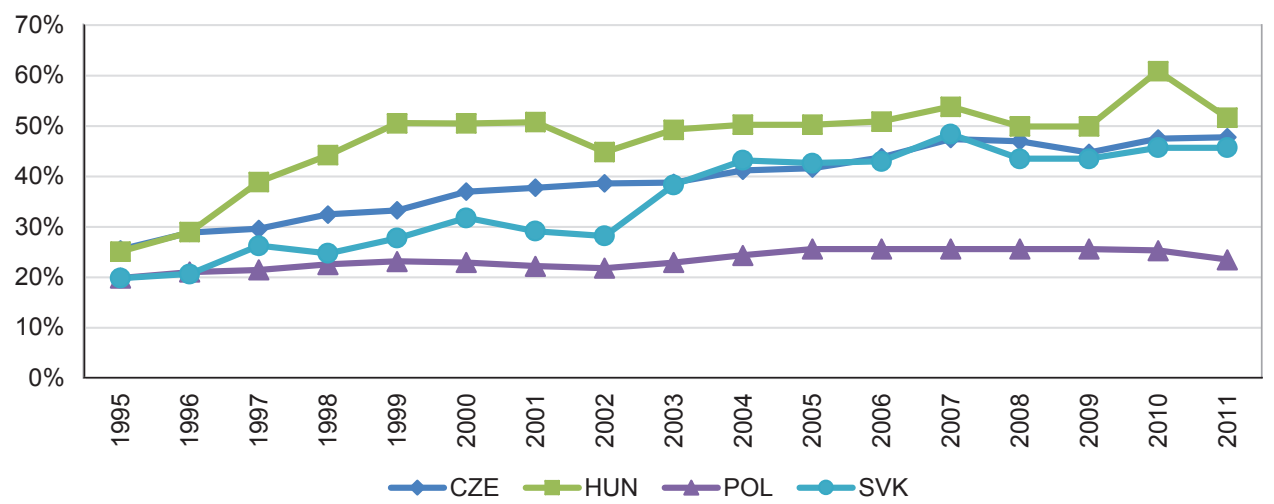

Source: World Input-Output Database, 2013 Release, authors' calculations

As the role of the export sector was becoming more and more important in the structure of V4 countries, the level of domestic demand share was declining. This is in line with previous findings with regard to the small open economies of the V4. The highest change in export share occurred in Hungary where the export sector grew at the highest rates and domestic demand dramatically declined.

Figure 3 | Development of Export Share in Total Final Demand in V4 (\%, 1995-2011)

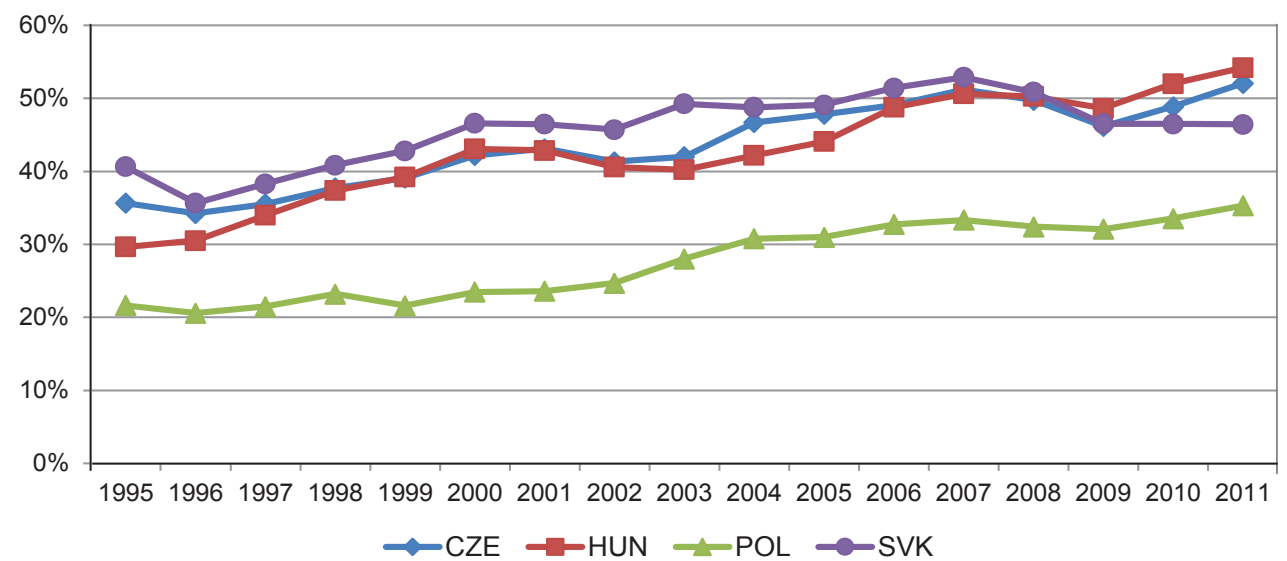

Source: World Input-Output Database, 2013 Release, authors' calculations

Habrman (2013) and Vintrová (2012) conclude that export-oriented industries are generating fewer jobs than industries oriented for domestic demand. Our results support such 
findings because mainly the increase in the export sector and the decline of the domestic demand share in total production led to the negative contribution of sectoral change of final demand to employment growth. The strongest effect was recorded in Hungary where this determinant was decreasing employment growth by more than one percentage point per year. On the other hand, this structural change had no significant influence on employment in Slovakia in the first period. Even though the share of the export in final demand rose in this period the negative employment effect was over-compensated by a positive employment effect in the government sector. It has changed in the second period which became known for the rapid growth of the export sector and the smaller role played by the government sector. These changes resulted in a negative contribution to employment growth on average by 1.5 percentage points per year.

Over the whole period, the size of the effects of the changes in final demand by sectors was similar to the contribution of changes in final demand by industries. Both effects were negative, they slowed down the employment growth and decreased the labour elasticity in V4 countries. The strongest impact was recorded in Hungary and Slovakia (mainly due to significant growth of exports in the second period). The Czech Republic was affected by this structural change as well, but with lower strength. The relatively lower ratio of export to total production in Poland caused the lowest impact of the change among all V4 countries in the first and also in the second period.

The last dimension which was analysed in case of structural change of final demand was its volume. It can be vaguely perceived as economic growth of country measured by GDP, even though they are not the same categories. GDP includes net exports only while our measure of final demand includes all final demand categories. We exclude direct imports from final consumption because we treat the changes in intermediate imports as a separate effect.

Our results show a very strong effect of final demand volume growth on employment growth in all V4 countries across all periods. The highest positive effect was recorded in Slovakia due to the rapid economic growth of this country in the second period. Poland, Hungary and the Czech Republic benefited from rapid economic growth as well, but at a slower pace of 2-3 percentage points. Such huge contributions of volume change contributed to employment growth just potentially. All other determinants were acting against employment growth which resulted in very mild and relatively poor results on the labour market in V4 countries. The positive effects of final demand growth were mitigated by negative effects in the industrial and sectoral structure of final demand in all analysed countries. The final demand structure has shifted towards less labour-intensive products and towards the production for export that is typically characterised by high labour productivity and therefore low employment growth effects.

\section{Conclusions}

The jobless growth, low labour elasticity and prevailing problems with unemployment in V4 countries revived the discussion about the possibility that economic policy might influence the relationship between economic growth and employment growth. It is well documented that even significantly lower economic growth rates could lead to higher increases in employment in advanced countries than in transition economies like the V4 countries. The necessity to close the technological gap and to increase the labour productivity have been identified as main factors behind this relation. Such empirical findings have led 
to contradictory policy recommendations. They either highlighted the positive role played by productivity growth in closing the technological gap or argued in favour of policies supporting even less productive and therefore more labour intensive activities.

In this article, we show that there are more policy options at hand that go beyond this trade-off between labour productivity growth and employment growth even in the shortrun. Based on the structural decomposition analysis of changes in employment in the V4 countries, we show that the change in overall employment can be decomposed into the contribution of several determinants. Labour productivity growth and economic growth are just two of six potential factors that influence the employment and labour elasticity. Among the other factors, changes in the structure of production and changes in the structure of final demand play a significant role. Our empirical findings show that, with a few exceptions, these structural changes played a negative role in employment development in all V4 countries across both analysed periods. A higher share of imported intermediates in total production and changes in the structure of production (with the Czech Republic as an exception) decreased the employment growth significantly. On top of that, changes in the final demand structure mitigated the positive impact of final demand volume growth on employment. The higher share of low labour intensive industries in final demand and the greater share of exports based on highly productive activities had a negative impact on low labour elasticity in all V4 countries. Based on these findings we can briefly list two policy recommendations. First, a higher share of intermediate products delivered by domestic suppliers could strengthen the link between final demand growth and employment growth. Second, the support of various services for industrial production could mitigate the problem with low labour elasticity to a large extent.

\section{References}

Ciobanu, C., Mattas, K., Psaltopoulos, D. (2004). Structural Changes in Less Developed Areas: An Input - Output Framework. Regional studies, 38(6), 603-614, https://doi. org/10.1080/003434042000240914

De Boer, P. (2009). Multiplicative Decomposition and Index Number Theory: An Empirical Application of the Sato-Vartia Decomposition. Economic Systems Research, 21(2), 163-174, https://doi.org/10.1080/09535310902937638

Dietzenbacher, E., Los, B. et al. (2013). The Construction of World Input-Output Tables in the WIOD Project. Economic Systems Research, 25(1), 71-98, https://doi.org/10.1080/09535314.2012.7 61180

Döpke, J. (2001). The "Employment Intensity" of Growth in Europe. [Accessed February 25, 2015]. Available at: http://www.econstor.eu/handle/10419/17746

Furceri, D., Crivelli, E., Toujas-Bernate, J. (2012). Can Policies Affect Employment Intensity of Growth? A Cross-Country Analysis. IMF Working Papers, 32, http://dx.doi. org/10.5089/9781475505689.001

Greskovits, B., Bohle, D. (2001). Development Paths on Europe's Periphery: Hungary's and Poland's Return to Europe Compared. Polish Sociological Review, 3-27.

Gunluk-Senesen, G., Senesen, U. (2011). Decomposition of Labour Demand by Employer Sectors and Gender: Findings for Major Exporting Sectors in Turkey. Economic Systems Research. [Accessed February 25, 2015]. Available at: http://www.tandfonline.com/doi/abs/10.1080/0 9535314.2011 .582031 
Habrman, M. (2013). Vplyv exportu na pridanú hodnotu a zamestnanost'v slovenskej ekonomike. (Impact of export on value added and employment in Slovak economy). Working Paper, No. 53. Bratislava: Ekonomický ústav, http://ekonom.sav.sk/uploads/journals/239_wp_53_ habrman.pdf

Huachu, Z. (2008). Structural Decomposition Analysis on Employment Changes in China. Chinese Journal of Population Science. [Accessed: 26 February, 2015]. Available at: http://en.cnki.com. cn/Article_en/CJFDTOTAL-ZKRK200802006.htm

Kapsos, S. (2005). The Employment Intensity of Growth. Ilo, 12.

Miller, R. E., Blair, P. D. (2009). Input-Output Analysis: Foundations and Extensions. Second Edition. Cambridge and New York: Cambridge University Press.

Skolka, J. (1989). Input-Output Structural Decomposition Analysis for Austria. Journal of Policy Modeling, 11(1), 45-66, https://doi.org/10.1016/0161-8938(89)90024-0

Tin, P. (2014). A Decomposition Analysis for Labour Demand: Evidence from Malaysian Manufacturing Sector. WSEAS Transactions on Business \& Economics. [Accessed: 25 February, 2015]. Available at: http://www.wseas.org/multimedia/journals/economics/2014/a065707119.pdf

Vintrová, R. (2012). Podceňování domácí poptávky v České republice. Scientia et Societas, VIII(2), 113-123.

Vltavská, K., Sixta, J. (2015). A Historical View on the Development of Czech Economy from 1970. Prague Economic Papers, 24(1), 105-122, https://doi.org/10.18267/j.pep.503

Vries, G. De, Erumban, A. (2012). Deconstructing the BRICs: Structural Transformation and Aggregate Productivity Growth. Journal of Comparative Economics, 40(2), 211-227, https://doi.org/10.1016/j.jce.2012.02.004

Yang, L., Lahr, M. L. (2010). Sources of Chinese Labor Productivity Growth: A Structural Decomposition Analysis, 1987-2005. China Economic Review, 21(4), 557-570, https://doi. org/10.1016/j.chieco.2010.05.012 